\title{
The Use of Amphibolite Melting Experiments in Constraining Conditions of Melting in Natural Amphibolite Nodules from the Venetia Kimberlite Pipes
}

\author{
Pretorius, W. ${ }^{1,2}$ and Barton, J. M., Jr. ${ }^{1}$ \\ ${ }^{1}$ Department of Geology, Rand Afrikaans University, P.O. Box 524, Auckland Park 2006, South Africa \\ ${ }^{2}$ Present address: 5B, 165 E 83rd St., New York City, NY 10028, U.S.A.
}

At surface, the $\sim 530 \mathrm{Ma}$ Venetia kimberlite pipes intrude predominantly Archean supracrustal and 2.5 to $2.0 \mathrm{Ga}$ granitic rocks and a minor amount of Archean and early Proterozoic tonalitic to trondhjemitic gneisses (e.g. Pretorius, 1996; Jaeckel et al., 1997). Integrated petrologic, geochemical and geophysical studies of upper lithospheric nodules from these pipes show that these country rocks, which are characteristic of the Central Zone of the Limpopo Belt, only extend to a depth of at most $10 \mathrm{~km}$. Below that level to a depth of at least $80 \mathrm{~km}$, the upper lithosphere is mafic and ultramafic composed first of various varieties of amphibolite and then also of gabbronorite, pyroxenite, garnet-quartz rocks and eclogite. The break between Central Zone lithologies and amphibolite may be a dêcollement (Barton and Pretorius, 1998) and reflective seismic data suggest that the rocks below are part of the Zimbabwe Craton (Roering et al., 1992).

Many nodules of amphibolite show evidence for partial melting and melt extraction (Pretorius, 1996), manifested by the formation of zoned poikilitic garnet containing melt inclusions and residual phases and serrate edges on many primary grains of amphibole and plagioclase. There is an increase in modal garnet, quartz, ilmenite and rutile next to primary amphibole and orthopyroxene and there are abundant fluid inclusion trails in residual quartz and garnet, indicating the importance of dehydration in melting processes.

Evidence for melting of three compositions of amphibolite were observed: felsic; intermediate and mafic. Unmelted compositions contain high modal percentages of sub- to euhedral hornblende and have low bulk Mg\#'s, low amphibole Mg\#'s and enriched chondrite normalized LREE patterns compared to restite compositions. Mafic compositions are characterized by the gradual production of between one and five metastable varieties of amphibole and a pyribole (pyroxene-amphibole hybrid), and finally a pyroxene bearing restite which has a low $\mathrm{Ce} / \mathrm{Lu}$ ratio $(\sim 12)$ relative to the unmelted composition $(\sim 23)$. Intermediate compositions, however, are conspicuously devoid of pyroxene and are dominated by garnet-quartz restites which have low La/Yb ratios $(\sim 0.4)$ compared to the unmelted composition $(\sim 1.7)$. Hornblende becomes more tschermakitic and plagioclase becomes more anorthitic as melting progresses.

Significant information was gained concerning the conditions of melting of amphibolite beneath the Venetia kimberlite pipes by comparing the intermediate and mafic unmelted and restite compositions to those used and produced in melting experiments (Wolf and Wyllie, 1993; 1994; Patino-Douce and Beard, 1995). Compared with the starting compositions used in the melting experiments, the compositions of unmelted amphibolite are more iron rich and magnesium and calcium poor. Grains of restitic garnet in Venetia amphibolite have prograde zonation profiles, in agreement with experimental observations and consistent with prograde melting. Incompatible components $\left(\mathrm{Na}_{2} \mathrm{O}, \mathrm{CaO}, \mathrm{K}_{2} \mathrm{O}\right)$ generally decrease as melting progresses concurrently with increases in $\mathrm{MgO}, \mathrm{FeO} \mathrm{Al}_{2} \mathrm{O}_{3}$ and $\mathrm{TiO}_{2}$. Silica saturation is an important parameter in the control of temperature of melting of amphibolite (Wolf, pers. comm., 1995) and hence we believe that the 
most significant deviation in P-T conditions from the experimental results will be due to variations in silica saturation. The major effect of the higher Fe/Mg ratios is to suppress formation of orthopyroxene or increase garnet crystallization.

The higher the activity of albite in intermediate amphibolite, the higher the melting pressure because garnet scavenges Ca (Green, 1969; Fram and Longhi, 1992; Rushmer, 1993; Patino-Douce and Beard, 1995). Garnet and plagioclase in intermediate Venetia amphibolite is $\mathrm{Ca}$ and $\mathrm{Na}$ rich (gross 26-27\%; An 23-32\%). For these compositions, plagioclase is only stable at pressures below $\sim 10 \mathrm{kbar}$, rutile and ilmenite above $\sim 10 \mathrm{kbar}$ and garnet above $\sim 12 \mathrm{kbar}$ (Patino-Douce and Beard, 1995). Thus the Venetia intermediate amphibolite containing garnet-rutile and ilmenite restites probably formed at pressures above $\sim 12 \mathrm{kbar}$ and possibly above $\sim 15 \mathrm{kbar}$ and temperatures above $\sim 850^{\circ} \mathrm{C}$. Mineral equilibrium geobarometry on Venetia intermediate amphibolite indicates pressures of $\sim 7$ to $10 \mathrm{kbar}$, showing decompression of at least $2 \mathrm{kbar}$ since melting.

In mafic amphibolite, melting reactions and resulting mineral textures are more complex (Wolf and Wyllie, 1994). During progressive melting of Venetia mafic amphibolite, five metastable amphibolite phases, pyribole (high-Ca cummingtonite), Ca-free cummingtonite, orthopyroxene/clinopyroxene, Fe-Ti oxides, sphene and garnet formed. Abundant growth of garnet and orthopyroxene takes place at temperatures of $\sim 850$ to $975^{\circ} \mathrm{C}$ and $<\sim 750^{\circ} \mathrm{C}$ respectively (Wolf and Wyllie, 1993). Garnet is stable at relatively high pressure ( $>\sim 11 \mathrm{kbar}$, Wyllie et al., 1997) but disappears at temperatures between $\sim 975$ and $1000^{\circ} \mathrm{C}$ (Wolf and Wyllie, 1993). Orthopyroxene becomes progressively unstable at pressures $>\sim 12 \mathrm{kbar}$ and between $\sim 925$ and $950^{\circ} \mathrm{C}$ and hornblende typically disappears at $>\sim 975^{\circ} \mathrm{C}$ (Wolf and Wyllie, 1993). It is often difficult to distinguish between cummingtonite and orthopyroxene in experimental charges due to their small grain sizes (Wolf, pers. comm., 1995) and hence evidence from the Venetia mafic amphibolite suggests that cummingtonite is also an important melt phase. Venetia mafic amphibolite that contains abundant hornblende and cummingtonite and therefore, probably melted at relatively low temperatures $\left(<\sim 850^{\circ} \mathrm{C}\right)$. As temperature increases above $\sim 850^{\circ} \mathrm{C}$, amphibolite containing garnet, cummingtonite, hornblende and orthopyroxene is produced. Above $\sim 950^{\circ} \mathrm{C}$, garnet and cummingtonite/orthopyroxene become progressively unstable, until the final assemblage of clinopyroxene, plagioclase \pm garnet predominates. Thus if relatively high temperatures $(\sim 975$ to $1000^{\circ} \mathrm{C}$ ) and low hydrous fluid flux were sustained during melting of Venetia mafic amphibolite, clinopyroxene rather than garnet would be the dominant residual phase as observed, in contrast to melting Venetia intermediate amphibolite. Garnet in Venetia mafic amphibolite is interpreted to be a result of subsolidus recrystallization as indicated by its chondrite normalized REE composition.

The lower to middle crust $(>\sim 10 \mathrm{~km})$ under the Venetia kimberlite pipes is anomalous compared to other lower to middle crustal estimates by being enriched in $\mathrm{FeO}, \mathrm{MnO}$ and $\mathrm{TiO}_{2}$ and lower in $\mathrm{Mg} / \mathrm{Fe}, \mathrm{SiO}_{2}, \mathrm{Al}_{2} \mathrm{O}_{3}, \mathrm{Na}_{2} \mathrm{O}$ and $\mathrm{K}_{2} \mathrm{O}$. This composition is attributed to first its amphibolitic nature and second, the extraction of large volumes of tonalitic to trondhjemitic magma during the Archean. Mass considerations and lithological proportions argue that these voluminous magmas are not present in the Central Zone of the Limpopo Belt (Barton and Pretorius, 1998). Precisely where they are remains a matter of contention although they could have formed major components of either the Northern Marginal Zone of the Limpopo Belt or the Kaapvaal or Zimbabwe Cratons.

\section{References}


Barton, J. M., Jr., and Pretorius, W., 1998, Implications of the lithospheric structure beneath the Venetia kimberlite pipes to the evolution of the Central Zone of the Limpopo Belt, Southern Africa: Spec. Publ. Peking Univ., China, (in press).

Fram, M. S., and Longhi, J., 1992, Phase equilibria of dikes associated with Proterozoic anorthosite complexes: Am. Min., 77, 605-616.

Green, T. H., 1969, Experimental studies on the origin of anorthosite Can. J. Earth Sci., 6, 427-440.

Jaeckel, P., Kroner, A., Kamo, S. L., Brandl, G., and Wendt, J. I., 1997, Late Archaean to early Proterozoic granitoid magmatism and high-grade metamorphism in the central Limpopo belt, South Africa: J. Geol. Soc. Lond., 154, 25-44.

Patino-Douce, A. E., and Beard, J. S., 1995, Dehydration melting of biotite gneiss and quartz amphibolite from 3 to 15 kbar: J. Petrol., 36, 707-738.

Pretorius, W., 1996, A geochemical and geophysical investigation of a suite of crustal and upper mantle nodules from Venetia kimberlite pipes, Limpopo Belt, South Africa: MSc thesis (unpubl.), Rand Afrikaans University, Johannesburg, 275 p.

Roering, C., Van Reenen, D. D., Smit, C. A., Barton, Jr., J. M., de Beer, J. H., de Wit, M. J., Stettler, E. H., Van Schalkwyk, J. F., Stevens, G., and Pretorius, S., 1992, Tectonic model for the evolution of the Limpopo Belt: Precamb. Res., 55, 539-552.

Rushmer, T., 1993, Experimental high-pressure granulites: some applications to natural mafic nodule suites and Archean granulite terranes: Geology, 21, 411-414.

Wolf, M. B., and Wyllie, P. J., 1993, Garnet growth during amphibolite anatexis: implications of a garnetiferous restite: J. Geol., 101, 357-373.

Wolf, M. B., and Wyllie, P. J., 1994, Dehydration melting of amphibolite at $10 \mathrm{kbar}$ : the effects of temperature and time: Contrib. Mineral. Petrol., 115, 369-383.

Wyllie, P.J., Wolf, M. B., and van der Laan, S. R., 1997, Conditions for formation of tonalites and trondhjemites: magmatic sources and products: in: M. J. de Wit and L. D. Ashwal (Eds.), Greenstone Belts, Claredon Press - Oxford, 256-266. 